\title{
Preliminary indication of ontogenetic and spatial variations in the whole otolith isotopic and elemental signatures of Solea solea in the Gulf of Lions (NW Mediterranean)
}

\author{
FABIEN MORAT $^{1}$, RAYMONDE LECOMTE-FINIGER ${ }^{2}$, DOMINIQUE BLAMART $^{3}$, \\ MICHEL ROBERT ${ }^{4}$ and YVES LETOURNEUR ${ }^{5}$ \\ ${ }^{1}$ Aix Marseille Université, Université du Sud Toulon-Var, CNRS/INSU, IRD, Mediterranean Institute of Oceanography \\ (MIO), UM 110, 13288 Marseille cedex 09, France. E-mail: fabien.morat@univ-amu.fr \\ ${ }^{2}$ Université de Perpignan, UMR 5244 CNRS-EPHE-UPVD, Avenue Paul Alduy, 66860 Perpignan cedex, France. \\ ${ }^{3}$ Laboratoire des Sciences du Climat et de l'Environnement, UMR 8212 CEA/CNRS/UVSQ, LSCE- Bât. 12, \\ Avenue de la Terrasse, 91198 Gif-sur-Yvette cedex, France. \\ ${ }^{4}$ Université de La Rochelle, Institut du littoral et de l'environnement, UMR 7266 LIENSs, 5 Allée de l'Océan, \\ 17071 La Rochelle Cedex 09, France. \\ ${ }^{5}$ Université de la Nouvelle-Calédonie, Laboratoire LIVE, BP R4, 145 Avenue James Cook, 98851 Nouméa cedex, \\ New Caledonia.
}

\begin{abstract}
SUMMARY: Knowledge of fish life cycles is important for exploited species. In the Mediterranean Sea, catches of common sole (Solea solea) have fluctuated widely since the 1970s. Solea solea displays an ontogenetic shift in habitat: sole larvae are marine, juveniles inhabit shallow marine waters and coastal lagoons and adults inhabit deeper marine waters. Although the results of this study were obtained using only a small set of individuals, the otolith elemental composition and isotopic ratios were investigated for the three life stages (post-larval, juvenile and adult) in order to acquire a better knowledge of the variability in environmental conditions experienced by the common sole at each life stage in the NW Mediterranean. Moreover, this study provides the first evaluation of the potential of whole otolith microchemistry for investigating habitat connectivity in sole populations from the Gulf of Lions. The elemental and isotopic signatures of otoliths of post-larvae captured in various environments appear to show variations related to the River Rhône inputs (high $\mathrm{Ba} / \mathrm{Ca}$ and low $\mathrm{Sr} / \mathrm{Ca}$ ratios). Juveniles appear to show significant variations in otolith elemental and isotopic compositions depending not only on the physico-chemical properties of water in the nurseries they inhabit (Rhône River, Thau or Mauguio lagoons), but also as a result of variations in the chemical composition of their surrounding sediments and in their benthic prey. Adults exhibit otolith differences for isotopic ratios only, which is probably linked to the River Rhône inputs. Finally, several significant relationships were observed between otolith elemental composition and fish size in specimens captured at the River Rhône mouth. However, these variations seem to be an indication of the composition acquired in each environment rather than a sign of ontogeny.
\end{abstract}

Keywords: flatfish, otolith microchemistry, stable isotope, coastal lagoon, River Rhône.

RESUMEN: INDICIOS PRELIMINARES DE VARIACIONES ONTOGENÉTICAS Y ESPACIALES EN LAS SEÑALES ISOTÓPICAS Y

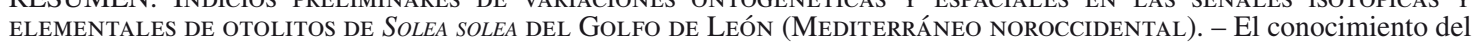
ciclo de vida es importante para las especies comerciales de peces. En el mar Mediterráneo, las capturas de lenguado común (Solea solea) han fluctuado ampliamente desde la década de los 70 . Solea solea presenta un cambio de hábitat ontogenético, las larvas son marinas, los juveniles viven en aguas marinas y en lagunas costeras, y los adultos viven en aguas marinas más profundas. Aunque los resultados de este estudio fueron obtenidos usando sólo un número pequeño de individuos, la composición de elemental los otolitos y las relaciones isotópicas fueron investigados en las tres etapas de vida (postlarval, juveniles y adultos) con el fin de adquirir un mejor conocimiento de la variabilidad en las condiciones ambientales que experimenta el lenguado común en cada etapa de la vida en el mediterráneo noroccidental. Por otra parte, este trabajo permite una primera evaluación del potencial de toda la microquímica de otolitos para la investigación de la conectividad del 


\begin{abstract}
hábitat en las poblaciones de lenguado en el Golfo de León. Las señales elementales e isotópicos de los otolitos de las postlarvas capturadas en diferentes entornos muestran variaciones en relación a los materiales aportados por del río Ródano (alta relación $\mathrm{Ba} / \mathrm{Ca}$ y baja relación $\mathrm{Sr} / \mathrm{Ca}$ ). Los juveniles parecen mostrar variaciones significativas en la composición elemental e isotópica de los otolitos dependiendo no sólo de las propiedades físico-químicas del agua en los viveros que habitan (Thau, Mauguio o el río Ródano), sino también como resultado de las variaciones en la composición química de los sedimentos circundantes y de su presa béntica. Los adultos presentan únicamente diferencias en las relaciones isotópicas de los otolitos, que está probablemente vinculado a por materiales aportados por el río Ródano. Por último, se observaron varias relaciones significativas entre la composición elemental de los otolitos y el tamaño de los peces en las muestras capturadas en la desembocadura del río Ródano. Sin embargo, estas variaciones parecen ser una indicación de la composición adquirida en cada entorno, más que ser debidas a la ontogenia.
\end{abstract}

Palabras clave: peces planos, microquímica de los otolitos, isótopos estables, laguna costera, río Ródano.

\section{INTRODUCTION}

Many marine fish species are subject to intensive fishing and stocks are overexploited (Garcia et al. 1999, Myers and Worm 2003). In coastal environments many fish migrate between habitats during larval, juvenile and adult stages. However, these coastal environments are subject to significant pressures in addition to fishing, such as pollution and eutrophication, which lead to habitat loss (Nixon 1995, Kemp et al. 2005). A better understanding of fish life cycles and use of these environments is essential for stock management.

The common sole, Solea solea (Linnaeus, 1758), is an important commercial flatfish of the eastern Atlantic Ocean and Mediterranean Sea. Catches of this species in the NW Mediterranean Sea from 1990 to 2009 dropped from roughly 520 to 130 tonnes per year, according to FAO figures (http://www.fao.org, Demaneche et al. 2009). The life cycle of the common sole is characterized by an ontogenetic shift in habitat (Salen-Picard et al. 2002), with juveniles inhabiting coastal lagoons and shallow coastal marine waters $(\leq 10 \mathrm{~m})$, whereas older individuals occupy the continental shelf from 20 to $150 \mathrm{~m}$ depth. Several studies dealing with the distribution of this species in the Gulf of Lions, NW Mediterranean Sea, have shown a higher density of individuals off the River Rhône mouth (Campillo et al. 1989, Gaertner et al. 1998). Moreover, a positive correlation has been established between the mean annual discharge of the River Rhône and the annual commercial catches of $S$. solea, with a time lag of five years (Salen-Picard et al. 2002) related to the fluctuations of soft-bottom communities dominated by polychaetes which are the prey of the common sole (Darnaude et al. 2001, Salen-Picard et al. 2002). A recent study based on otolith shape analysis (Mérigot et al. 2007) showed that several local populations of sole inhabit the Gulf of Lions. However, in addition to the relationship between otolith shape and growth rate, shape is seen to be strongly dependent on changes in environmental conditions and fish size (Reddin et al. 1988, Campana and Casselman 1993, Friedland and Reddin 1994, Pothin et al. 2006, Tracey et al. 2006, Morat et al. 2012). However, the exact nature of past environmental changes or migrations is invisible in the studies of otolith shape.

Otoliths, the "flight recorder" of teleost fish (Lecomte-Finiger 1999), have been widely used to characterize populations and stocks on the basis of chemical elemental composition (Campana et al. 1995, 1999, 2000, Gillanders and Kingsford 2000, Rooker et al. 2003, Jónsdóttir et al. 2006, Vasconcelos et al. 2008, Tanner et al. 2011). They record environmental changes with great precision using other markers such as the composition of chemical elements and isotopic ratios (see Campana 1999 for an extensive review). Otoliths exhibit three key features: (i) they grow continuously from the birth of fish to their death; (ii) they are metabolically inert, so newly-deposited material is neither resorbed nor reworked after deposition (Campana and Neilson 1985); and (iii) their uptake of trace elements as they grow reflects the physical and chemical environment (Fowler et al. 1995, Gallahar and Kingsford 1996), albeit with significant physiological regulation (Kalish 1989, Farrell and Campana 1996). Environmental availability and temperature also affect the isotope ratios of elements. For example, $\delta^{18} \mathrm{O}$ can be used to estimate the temperatures at which carbonates are formed (Kalish 1991, Thorrold et al. 1997, Rooker et al. $2008 \mathrm{a}, \mathrm{b})$. The carbon isotopic ratio can provide information on metabolic processes and on the source of the carbon involved during calcification (Kalish 1991, Schwarcz et al. 1998). Given the capacity of otoliths to incorporate both chemical elements and isotope ratios (i.e. the "elemental fingerprints") from the environment and to grow continuously, the otolith can be used as a life-history record reflecting habitat changes during the fish's lifetime.

This paper investigates differences in the otolith isotopic and elemental signatures between the three life stages (post-larval, juvenile and adult) in order to acquire a better knowledge of the variability in environmental conditions experienced by the common sole at each life stage in the NW Mediterranean. Moreover, this study provides the first evaluation of the potential of whole otolith microchemistry for the investigation of habitat connectivity in sole populations from the Gulf of Lions.

\section{MATERIALS AND METHODS}

\section{Sampling}

In the Mediterranean Sea, the common sole undergoes an ontogenetic shift of habitat during its life cycle. Larvae are marine, juveniles inhabit shallow marine 
TABLE 1. - Numbers of left sagittae of Solea solea analysed for elemental composition (EC) and isotopic fingerprint (I) from different sites, seasons and depths in the NW Mediterranean Sea. TL, total fish length.

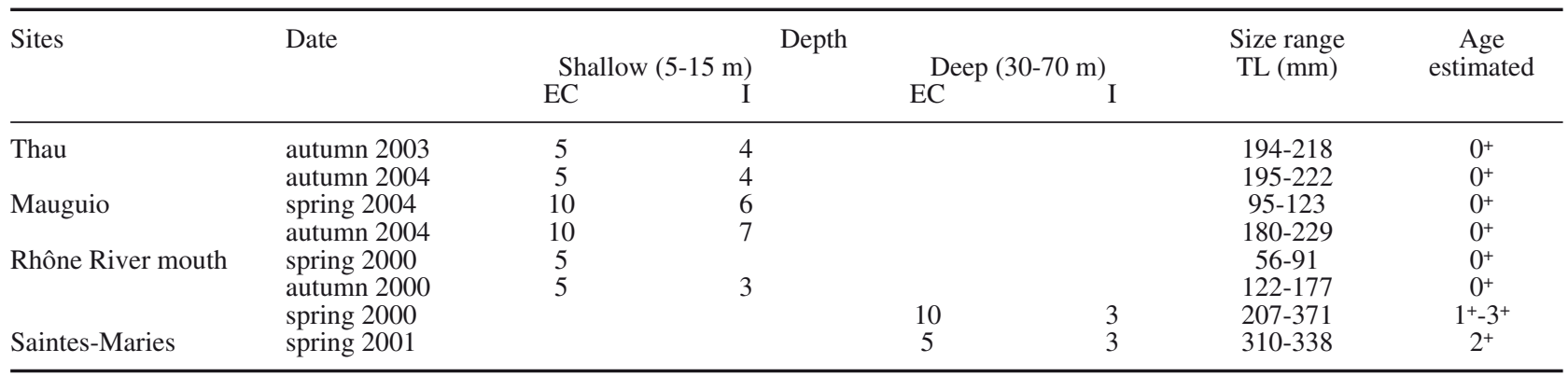

waters, estuaries or coastal lagoons and adults live in deeper marine environments. The sampling of each life stage was conducted according to these characteristics.

Juvenile habitats. Juvenile sole inhabit the shallow waters at the River Rhône mouth (5-15 m, Campillo 1992). This river is $812 \mathrm{~km}$ long and has a catchment area of $95500 \mathrm{~km}^{2}$. Its discharge varies between 500 and $11000 \mathrm{~m}^{3} \mathrm{~s}^{-1}$, with a mean value of $1700 \mathrm{~m}^{3} \mathrm{~s}^{-1}$. The salinity in very shallow waters off the River Rhône mouth can drop to about 6 , and the temperature range is $13^{\circ} \mathrm{C}$ to $21^{\circ} \mathrm{C}$. Juveniles can also inhabit coastal lagoons. Two types of coastal lagoon on the central coast of the Gulf of Lions were sampled: Mauguio Lagoon, a desalted coastal lagoon and Thau Lagoon, a more marine lagoon. Mauguio Lagoon has a surface area of $32 \mathrm{~km}^{2}$ and a catchment area of $410 \mathrm{~km}^{2}$. Its mean depth is $0.8 \mathrm{~m}(\max .1 .30 \mathrm{~m})$ and it has only one permanent communication channel with the open sea. The salinity varies between 18 and 32 and the water temperature ranges from $7^{\circ} \mathrm{C}$ to $24^{\circ} \mathrm{C}$ (Ifremer 2008). Thau Lagoon has a surface area of $75 \mathrm{~km}^{2}$ and a catchment area of $285 \mathrm{~km}^{2}$. Its mean depth is $4 \mathrm{~m}(\max .10 \mathrm{~m})$ and it has two permanent seawater inlets. Salinity usually varies between 32 and 39, and water temperature ranges from $5^{\circ} \mathrm{C}$ to $25^{\circ} \mathrm{C}$ (Ifremer 2008).

Adult habitats. Adults live on the continental shelf and are abundant off the River Rhône mouth (Campillo 1992, Gaertner et al. 1998). The salinity and temperature ranges for this deep water environment are $37-38^{\circ} \mathrm{C}$ and $12-14^{\circ} \mathrm{C}$, respectively. In Saintes-Maries, salinity and water temperature characteristics are similar to those observed in the deep waters off the river mouth.

Fish captured in spring in Mauguio Lagoon and in the shallow waters at the Rhône River mouth were post-larval individuals (Table 1, Fig. 1). Fish captured in lagoons and in shallow waters at the River Rhône mouth in autumn were young of the year (Table 1, Fig. 1). Fish captured in the deep waters at the River Rhône mouth and at Saintes-Maries were older individuals (Table 1, Fig. 1). Their otoliths consist mainly of material deposited during the larval/juvenile or adult life stages, respectively, so they primarily reflect the environmental conditions that prevail in the habitats of larvae, juveniles or adults of the species.

A total of 85 individuals of Solea solea were sampled (Table 1). Left otoliths (sagittae) were extracted

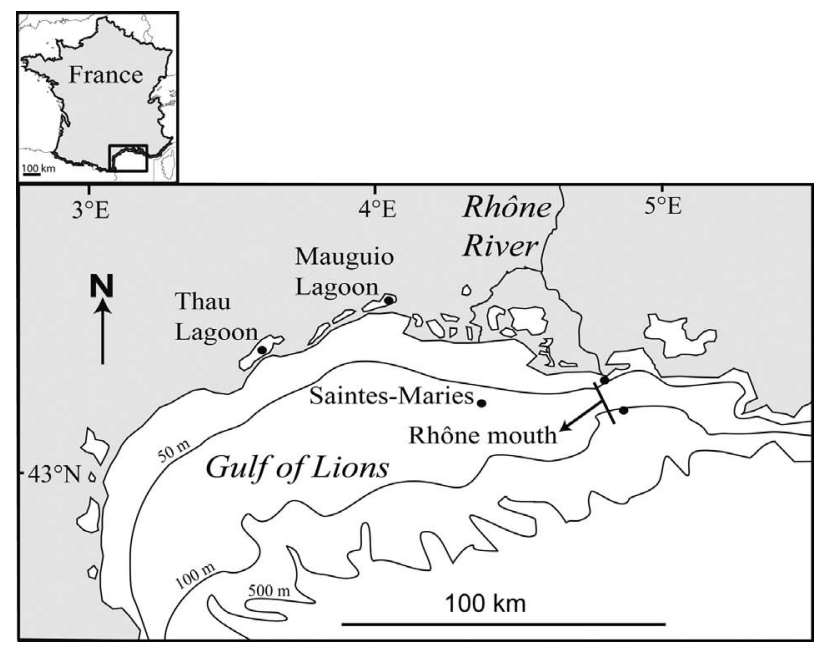

FIG. 1. - Location of study sites in the northwestern Mediterranean Sea. All sites were used for otolith trace elemental analyses and for determination of the stable isotopic signatures of otoliths.

with non-metallic forceps. Immediately following extraction, the otoliths were placed in distilled water for cleaning and for removal of residual tissues from the macula and the vestibule, using fine tweezers. Once cleaned, the otolith pairs were dried and weighed $(1.03-42.11 \mathrm{mg})$ and kept dry in Eppendorf tubes. Fifty-five otoliths were used for the determination of the chemical composition and 30 for $\delta^{18} \mathrm{O}-\delta^{13} \mathrm{C}$ stable isotope analysis (Table 1). Because the life cycle of the common sole is characterized by an ontogenetic shift of habitat, fish sampled at the four sites showed differences in total fish length (Table 1).

\section{Elemental analyses}

Elemental analyses were carried out to characterize spatial differences at three life stages of the common sole at various sites. The left otoliths were analysed with Inductively Coupled Plasma Mass Spectrometry (ICPMS, mass 700, Varian, Inc. Corporate Headquarters, Palo Alto, CA, USA) for $\mathrm{Al}, \mathrm{Mn}, \mathrm{Co}, \mathrm{Cu}, \mathrm{Cd}, \mathrm{Ba}$ and $\mathrm{Pb}$, and with ICP Atomic Emission Spectroscopy (ICP-AES, Vista-PRO Varian, Inc. Corporate Headquarters, Palo Alto, CA, USA) for $\mathrm{Li}, \mathrm{Mg}, \mathrm{Fe}, \mathrm{Ca}$ and Sr. The use of both machines ensured the best resolution for each element. Each otolith was dissolved in 
$2 \mathrm{~mL}$ of Suprapur nitric acid (65\%). Solutions were mineralized for 2 hours at $110^{\circ} \mathrm{C}$ to $120^{\circ} \mathrm{C}$ and dissolved in $5 \mathrm{~mL}$ of Suprapur nitric acid (5\%). Indium was used as an internal standard $\left(0.1 \mathrm{mg} \mathrm{L}^{-1}\right)$. A standard range was carried out with a multi-element solution (ASTASOL MIX MO101, Analytika, Prague, Czech Republic). The quality control was performed with an international standard (Bone Meal, NIST SRM1486), and two internal standards (TORT 2, lobster hepatopancreas, certified by the National Research Council, Canada, and another obtained from otolith crushing, Campana pers. comm. 2006).

The otolith elemental composition revealed 11 elements above the limit of detection: 1 minor element ${ }^{86} \mathrm{Sr}$ ) and 10 trace elements $\left({ }^{7} \mathrm{Li},{ }^{24} \mathrm{Mg},{ }^{26} \mathrm{Fe},{ }^{27} \mathrm{Al}\right.$, ${ }^{55} \mathrm{Mn},{ }^{59} \mathrm{Co},{ }^{63} \mathrm{Cu},{ }^{111} \mathrm{Cd},{ }^{135} \mathrm{Ba}$ and ${ }^{208} \mathrm{~Pb}$ ). The elemental classification is in agreement with Campana (1999).

\section{Stable isotopic composition}

Otoliths were cleaned and weighed to ensure a suitable sample mass of carbonate for isotopic analysis. To avoid possible contamination by organic matter $(<1 \mathrm{wt}$ $\%$ ), the samples were baked at $380^{\circ} \mathrm{C}$ for 45 minutes (Blamart et al. 2002). All isotope analyses were carried out on a Finnigan Mat Delta + mass spectrometer coupled with an automated preparation line.

The results are given in the conventional $(\delta \%$ ) notation expressed in parts per mil against the V-PDB standard (Vienna Pee Dee Belemnite: Coplen et al. 1983), where:

$$
\delta_{\text {sample }}=\left(\frac{R_{\text {sample }}}{R_{\text {standard }}}-1\right) \times 10^{3}
$$

Reproducibility was $0.04 \%$ and $0.05 \%$, respectively, for the carbon and the oxygen isotopes. Variation in the isotopic signatures in otoliths was estimated using the coefficient of variation $\left(\mathrm{CV} \delta^{18} \mathrm{O}\right.$ and $\left.\mathrm{CV} \delta^{13} \mathrm{C}\right)$.

$$
C V \delta X=\frac{s d_{X} \times 100}{\bar{m}_{X}}
$$

where $s d_{X}$ was the standard deviation of samples and $\bar{m}_{X}$ the mean of samples.

\section{Data analyses}

Otolith elemental concentrations and isotopic composition were compared within each life stage by MANOVAs in order to observe differences between sites. All differences between sites were tested with Fisher LSD post-hoc tests. Before statistical testing, elemental ratios were examined for normality and homogeneity among factor levels. Variations in elemental ratios in otoliths according to fish size were analysed with Pearson linear correlation at the River Rhône mouth.

Canonical discriminant analyses (CDA) were performed to investigate the ontogenetic effect on the chemical elemental composition of otoliths. The performance of the CDA was assessed with Wilk's $\lambda$. This statistic is the ratio of intragroup variance to total variance, and provides an objective means of calculating the chance-corrected percentage of agreement between real and predicted group membership (Titus et al. 1984). The values of Wilk's $\lambda$ range from zero to one: the closer Wilk's $\lambda$ is to zero, the more accurate is the discriminating power of the CDA. The two principal discriminant functions were characterized by linear combinations of variables. To validate the performance of the CDA, a leave-one-out cross-validation statistic was used (Ramsay 2005).

\section{RESULTS}

\section{Larval signatures}

The elemental composition of otoliths revealed significant differences between post-larvae captured in shallow water at the River Rhône mouth and in Mauguio Lagoon in spring 2000 and spring 2004, respectively (Table 2). Post-larvae from Mauguio Lagoon showed significantly lower $\mathrm{Sr} / \mathrm{Ca}$ and $\mathrm{Co} / \mathrm{Ca}$ ratios and higher $\mathrm{Ba} / \mathrm{Ca}, \mathrm{Mn} / \mathrm{Ca}$ and $\mathrm{Mg} / \mathrm{Ca}$ ratios than postlarvae from shallow water at the River Rhône mouth (Fig. 2). Moreover, Mauguio fish otoliths had the lowest isotopic ratios (Table 3, Fig. 3) with $\delta^{13} \mathrm{C}=-10.50$ $( \pm 0.27)$ and $\delta^{18} \mathrm{O}=-1.86( \pm 0.01)$.

\section{Juvenile signatures}

No significant difference was observed for either the isotopic or the elemental signatures of otoliths from juveniles captured in Thau Lagoon in autumn 2003 and in autumn 2004 (Table 3). Therefore, these two years were pooled in all other comparisons.

Although sampling year varied according to the nursery site, significant differences were observed for otolith isotopic and elemental signatures of juvenile soles from the River Rhône mouth and from the Thau and Mauguio lagoons (Table 2). Juveniles captured in Thau Lagoon showed higher values of $\mathrm{Sr} / \mathrm{Ca}, \mathrm{Co} / \mathrm{Ca}$, $\mathrm{Cu} / \mathrm{Ca}, \delta^{13} \mathrm{C}$ and $\delta^{18} \mathrm{O}$ than those captured in Mauguio Lagoon. Moreover, they also showed higher values of $\mathrm{Sr} / \mathrm{Ca}, \mathrm{Ba} / \mathrm{Ca}, \mathrm{Mn} / \mathrm{Ca}, \mathrm{Co} / \mathrm{Ca}, \mathrm{Cd} / \mathrm{Ca}$ and $\delta^{13} \mathrm{C}$ than juveniles captured at the River Rhône mouth. The juveniles captured at the River Rhône mouth showed higher values of $\delta^{13} \mathrm{C}$ and $\delta^{18} \mathrm{O}$ than those captured in Mauguio Lagoon, and no difference for other elements (Tables 2, 3 and Figs 2, 3).

\section{Adult signatures}

The elemental compositions of otoliths of adult fish captured in deep water at the River Rhône mouth and at Saintes-Maries did not reveal significant differences (Table 2, Fig. 2). However, higher $\delta^{13} \mathrm{C}$ and $\delta^{18} \mathrm{O}$ values were observed for otoliths from adult fish captured at Saintes-Maries (Tables 2, 3, Fig. 3). 

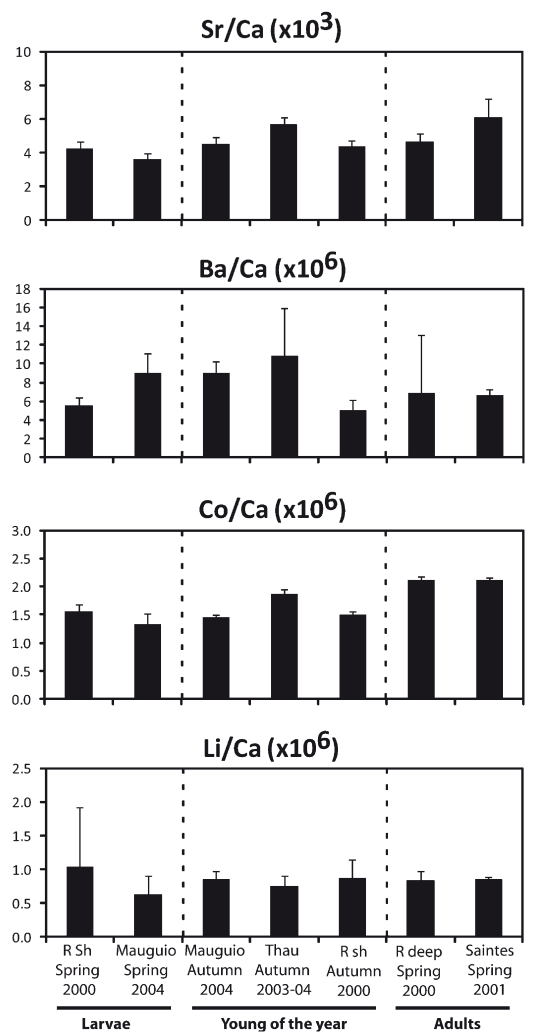
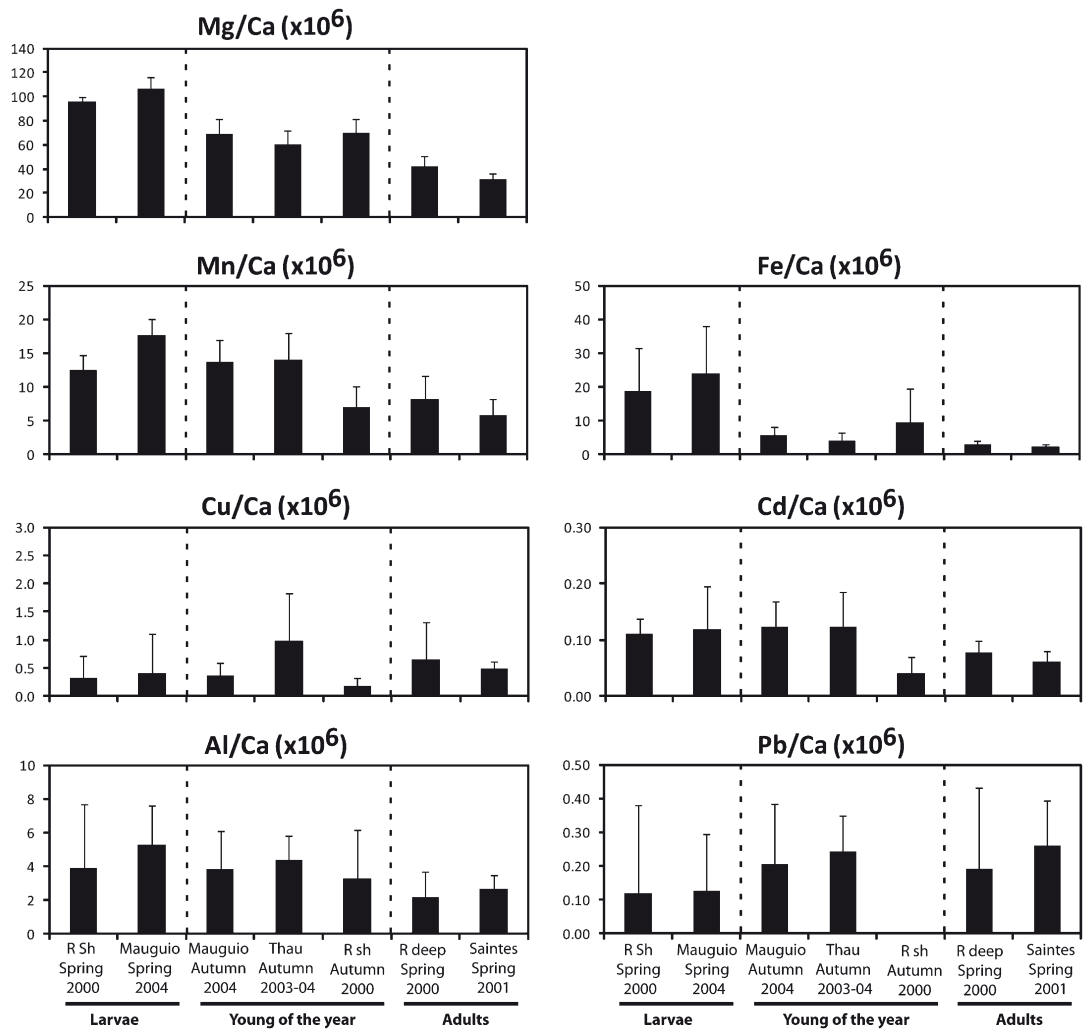

Fig. 2. - Mean ( \pm sd) of elemental ratios by site (R Sh, Rhône shallow; R deep, Rhône deep). Both years in Thau coastal lagoon are grouped. Life stages are mentioned below the graphics.

TABLE 2. - Results of one-way MANOVAs achieved with elemental composition (in ratios to calcium) and isotopic ratios of otoliths for each life stage studied. NS, non-significant; Thau aut. grp, Thau autumn 2003 and 2004 grouped.

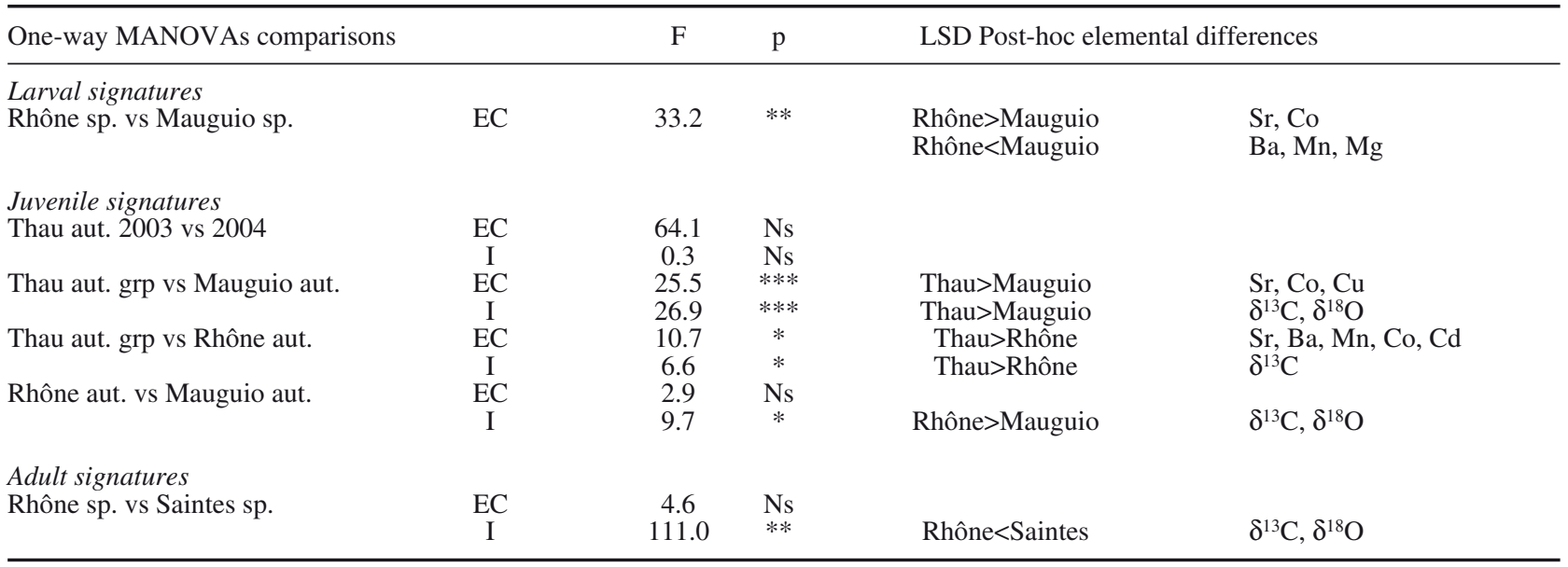

TABLE 3. - Mean ( \pm sd) otolith $\delta^{13} \mathrm{C}$ and $\delta^{18} \mathrm{O}$ for Solea solea caught from four sites in the NW Mediterranean expressed in \%o versus PDB. Variations in ratios are indicated by the coefficient of variation $(\mathrm{CV})$.

\begin{tabular}{|c|c|c|c|c|c|}
\hline Site and date & $\mathrm{N}$ & $\delta^{18} \mathrm{O}$ & $\delta^{13} \mathrm{C}$ & $\mathrm{CV} \delta^{18} \mathrm{O}$ & $\mathrm{CV} \delta^{13} \mathrm{C}$ \\
\hline Mauguio: spring 2004 & 6 & $-1.86( \pm 0.07)$ & $-10.50( \pm 0.27)$ & 3.65 & 2.38 \\
\hline Mauguio: autumn 2004 & 7 & $-0.44( \pm 0.59)$ & $-8.78( \pm 1.81)$ & 123.70 & 19.05 \\
\hline Thau: autumn 2003 & 4 & $1.11( \pm 0.56)$ & $-2.13( \pm 0.69)$ & 4.87 & 15.04 \\
\hline Thau: autumn 2004 & 4 & $0.86( \pm 0.35)$ & $-2.92( \pm 1.86)$ & 3.58 & 26.10 \\
\hline Rhône River mouth: shallow; autumn & 3 & $1.20( \pm 0.07)$ & $-4.59( \pm 0.85)$ & 43.54 & 28.06 \\
\hline Rhône River mouth: deep; spring & 3 & $1.66( \pm 0.03)$ & $-3.86( \pm 1.23)$ & 35.54 & 55.27 \\
\hline Saintes-Maries: deep; spring & 3 & $2.35( \pm 0.06)$ & $-1.75( \pm 0.19)$ & 2.13 & 9.12 \\
\hline
\end{tabular}



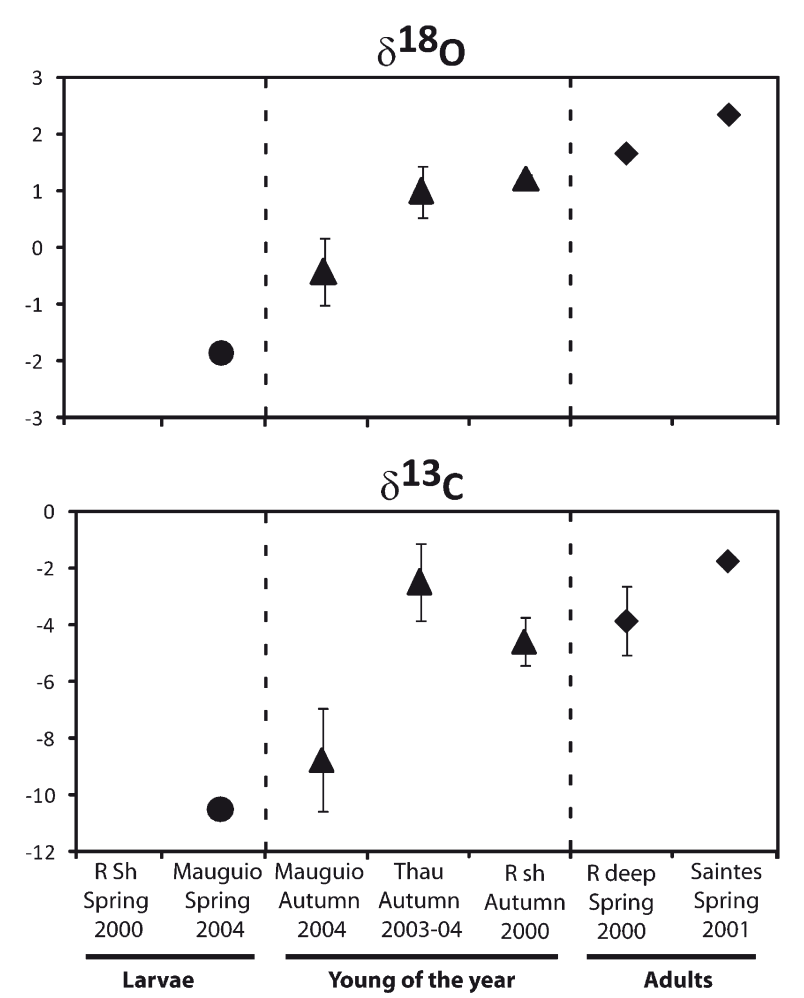

FIG. 3. - Mean ( \pm sd) of isotopic ratios by site (R Sh, Rhône shallow; $\mathrm{R}$ deep, Rhône deep). Both years in Thau coastal lagoon are grouped. Life stages are mentioned below the graphics

TABLE 4. - Results of linear regressions between elemental composition and fish size (TL) in the River Rhône mouth.

\begin{tabular}{lcccl}
\hline & Slope & y-intercept & $\mathrm{r}^{2}$ & $\mathrm{p}$ \\
\hline $\mathrm{Sr} / \mathrm{Ca}$ & $2.0^{*} 10^{-3}$ & 4.050 & 0.178 & $\mathrm{Ns}$ \\
$\mathrm{Mg} / \mathrm{Ca}$ & $-24.3^{*} 10^{-2}$ & 111.770 & 0.903 & $* * *$ \\
$\mathrm{Li} / \mathrm{Ca}$ & $-7.0^{*} 10^{-4}$ & 1.043 & 0.023 & $\mathrm{Ns}$ \\
$\mathrm{Fe} / \mathrm{Ca}$ & $-6.9 * 10^{-2}$ & 22.520 & 0.429 & $* *$ \\
$\mathrm{Ba} / \mathrm{Ca}$ & $4.5 * 10^{-3}$ & 5.190 & 0.010 & $\mathrm{Ns}$ \\
$\mathrm{Mn} / \mathrm{Ca}$ & $-1.7 * 10^{-2}$ & 12.402 & 0.203 & $*$ \\
$\mathrm{Al} / \mathrm{Ca}$ & $-7.6^{*} 10^{-3}$ & 4.418 & 0.082 & $\mathrm{Ns}$ \\
$\mathrm{Co} / \mathrm{Ca}$ & $2.8^{*} 10^{-3}$ & 1.247 & 0.744 & $* * *$ \\
$\mathrm{Cu} / \mathrm{Ca}$ & $1.4 * 10^{-3}$ & 0.155 & 0.068 & $\mathrm{Ns}$ \\
$\mathrm{Cd} / \mathrm{Ca}$ & $-7.7 * 10^{-5}$ & 0.093 & 0.048 & $\mathrm{Ns}$ \\
\hline
\end{tabular}

\section{Ontogenetic effects}

The ontogenetic effect on the elemental composition of otoliths was tested for fish of all three life stages, all captured in 2000 at the River Rhône mouth. Of the 11 elemental ratios, four showed a significant relationships with fish size (Table 4). An increase in the $\mathrm{Co} / \mathrm{Ca}$ ratio and a decrease in the $\mathrm{Mg} / \mathrm{Ca}, \mathrm{Fe} / \mathrm{Ca}$ and $\mathrm{Mn} / \mathrm{Ca}$ ratios were observed with increasing fish size.

Moreover, the CDA achieved with the elemental composition of otoliths indicated a clear differentiation
TABLE 5. - Percentage success rate reclassifying sole to life stage using a cross-validated CDA and whole otolith elemental ratios. Rows represent actual groups while columns represent predicted groups. Correct classifications are given in bold characters; YOY, young of the year.

\begin{tabular}{lcccc}
\hline & Larvae & YOY & Adults & Total \\
\hline Larvae & $\mathbf{9 3 . 3}$ & 6.7 & 0 & 100 \\
YOY & 12.0 & $\mathbf{8 8 . 0}$ & 0 & 100 \\
Adults & 0 & 0 & $\mathbf{1 0 0}$ & 100 \\
\hline
\end{tabular}

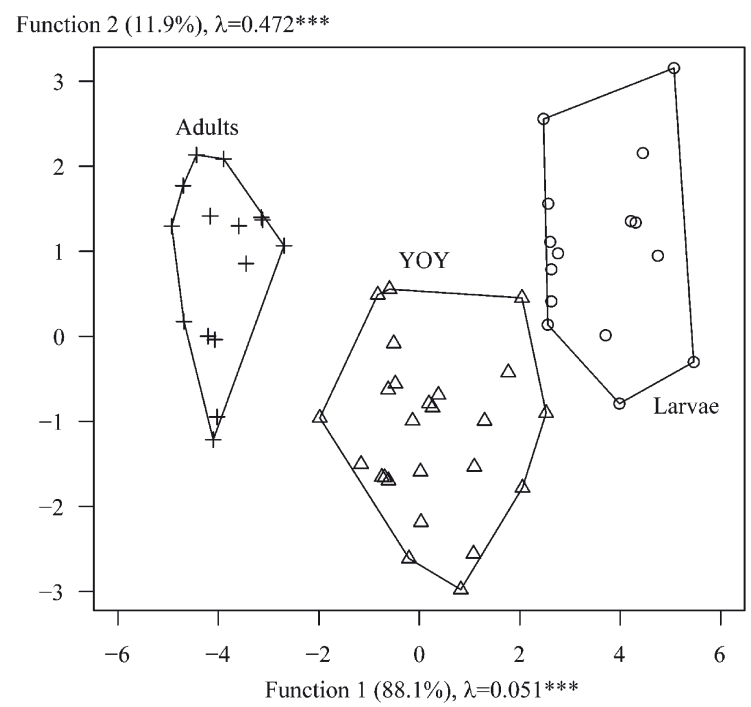

FIG. 4. - Plot of the CDA carried out with multi-element fingerprints of life stages otolith signatures for all sites grouped: (o) larvae, young of the year (YOY, $\Delta$ ), adults $(+)$ for all sites grouped. Results of cross-validation in percentage are shown in Table 6.

of the three fish life stages: larvae, juveniles (young of the year) and adults, with a correct reclassification of $92.7 \%$ of individuals (Fig. 4, Table 5). The first discriminant function represented the majority of the total variability $(88.1 \%)$ and separated the three life stages. This function was driven by six ratios: $\mathrm{Mg} / \mathrm{Ca}, \mathrm{Mn} / \mathrm{Ca}$, $\mathrm{Al} / \mathrm{Ca}, \mathrm{Co} / \mathrm{Ca}$ and $\mathrm{Cd} / \mathrm{Ca}$ (Table 6). Life stage separation was linked to these ratios and adults were mainly characterized by higher $\mathrm{Co} / \mathrm{Ca}$ ratios and larvae by $\mathrm{Mg} / \mathrm{Ca}$. The second discriminant function represented $11.9 \%$ of the total variability and was driven by four ratios: $\mathrm{Sr} / \mathrm{Ca}, \mathrm{Fe} / \mathrm{Ca}, \mathrm{Ba} / \mathrm{Ca}$ and $\mathrm{Cu} / \mathrm{Ca}$ (Table 6). This function separated out primarily the young of the year, which were linked to higher $\mathrm{Sr} / \mathrm{Ca}$ and $\mathrm{Cu} / \mathrm{Ca}$ ratios.

\section{DISCUSSION}

Many marine applications of multi-element otolith composition analysis have been published (Gillanders and Kingsford 1996, Campana et al. 2000, Gillanders

TABLE 6. - Results of CDA carried out on elemental ratios. Coefficient-driven functions 1 and/or 2 are presented in bold characters.

\begin{tabular}{|c|c|c|c|c|c|c|c|c|c|c|c|c|c|}
\hline & Wilks $\lambda$ & $P$ value & Variability in \% & $\begin{array}{l}\text { Functic } \\
\mathrm{Sr} / \mathrm{Ca}\end{array}$ & $\begin{array}{l}\mathrm{Mg} / \mathrm{Ca} \\
\end{array}$ & $\begin{array}{c}\text { ardized c } \\
\mathrm{Li} / \mathrm{Ca}\end{array}$ & $\begin{array}{c}\text { oefficien } \\
\mathrm{Fe} / \mathrm{Ca}\end{array}$ & $\mathrm{Ba} / \mathrm{Ca}$ & $\mathrm{Mn} / \mathrm{Ca}$ & $\mathrm{Al} / \mathrm{Ca}$ & $\mathrm{Co} / \mathrm{Ca}$ & $\mathrm{Cu} / \mathrm{Ca}$ & $\mathrm{Cd} / \mathrm{Ca}$ \\
\hline Function 1 & 0.051 & $<0.001$ & 88.1 & 0.328 & 0.796 & 0.081 & 0.117 & 0.050 & 0.067 & 0.223 & -0.620 & 0.096 & 0.151 \\
\hline Function 2 & 0.472 & $<0.001$ & 11.9 & $-\mathbf{0 . 5 8 9}$ & 0.390 & -0.152 & 0.730 & 0.137 & -0.310 & -0.534 & 1.023 & -0.376 & 0.326 \\
\hline
\end{tabular}


2002, Vasconcelos et al. 2008, Cuvelier et al. 2010, Tanner et al. 2011, Mercier et al. 2012), but few studies have investigated concomitantly the use of stable isotopes ratios (carbon and oxygen) and elemental composition (Kerr et al. 2007, Tanner et al. 2011). Although preliminary, the results from the present work suggest that otolith elemental and isotopic signatures may help to elucidate habitat connectivity of the common sole in the Gulf of Lions.

\section{Larval life stage}

Of the 11 elemental ratios measured in otoliths of the common sole, 5 showed significant differences between fish post-larvae captured in shallow waters at the River Rhône mouth and those caught in Mauguio Lagoon in spring. Although the results were obtained using only a small set of individuals, the differences observed suggest that these fish lived in different environments during the larval stage. Otoliths of post-larvae captured at the River Rhône mouth showed higher values of $\mathrm{Sr} / \mathrm{Ca}$ and $\mathrm{Co} / \mathrm{Ca}$ and lower values of $\mathrm{Ba} / \mathrm{Ca}, \mathrm{Mn} / \mathrm{Ca}, \mathrm{Mg} / \mathrm{Ca}$ than those of post-larvae captured in Mauguio Lagoon. Four of the five elements indicated relationships with environmental characteristics of the water. The otolith $\mathrm{Sr} / \mathrm{Ca}$ ratio has often been used as a proxy of salinity (Limburg 1995, Campana 1999, Secor and Rooker 2000, Zlokovitz et al. 2003, Zimmerman 2005). The $\mathrm{Co} / \mathrm{Ca}$ ratio of otoliths has the same characteristics in higher proportions in marine water. $\mathrm{Ba} / \mathrm{Ca}$ and $\mathrm{Mn} /$ $\mathrm{Ca}$ ratios are higher in freshwater than in marine water (Panfili et al. 2002, Hamer et al. 2006, Bradbury et al. 2008, Tabouret et al. 2010). All these variations in ratios suggest that the fish post-larvae captured in Mauguio Lagoon in spring had been exposed to more desalted waters than those captured at the River Rhône mouth. However, in the Mediterranean Sea, the common sole reproduces in winter, and this probably takes place in proximity to the River Rhône mouth (Quéro and Vayne 1997). The fish post-larvae analysed were captured in 2000 at the River Rhône mouth and in 2004 in Mauguio Lagoon. During these years, the winter flow of the River Rhône varied considerably. In winter 1999-2000 the flow was normal, with a maximal water discharge of $3300 \mathrm{~m}^{3} \mathrm{~s}^{-1}$, whereas in winter 2003-2004 the river experienced a 100-year return flood with a maximal water discharge of more than $10000 \mathrm{~m}^{3} \mathrm{~s}^{-1}$ (Compagnie Nationale du Rhône, Miralles et al. 2006). This difference could explain why the otoliths of fish born in winter 2003-2004 exhibit elemental characteristics typical of fish from less salty water than fish born in winter 1999-2000. In otoliths, $\delta^{13} \mathrm{C}$ reflects the metabolism (diet) and dissolved inorganic carbon (DIC) signatures (Solomon et al. 2006). The $\delta^{13} \mathrm{C}$ of the River Rhône DIC is lower (between -10.2 and $-9.0 \%$ ) than the $\delta^{13} \mathrm{C}$ of marine water (between 0 and $2 \%$; Aucour et al. 2003). The very low $\delta^{13} \mathrm{C}$ value of otoliths from fish post-larvae captured in Mauguio Lagoon in spring 2004 may be due to the influence of the River Rhône waters during the larval life stage. These differences in isotopic and elemental compositions of larval stage otoliths seem to indicate inter-annual variations in the environmental conditions encountered by these sole larvae in the periods studied rather than spatial difference in the larval stage habitat of these fish.

\section{Juvenile life}

Otolith growth is greater during the juvenile life stage than in the larval phase and for this reason the signatures observed in otoliths from nurseries seem to reflect principally the juvenile stage. Indeed, the juvenile period makes up $~ 90 \%$ of a juvenile otolith. Although our results were obtained on a small number of individuals for each year, no differences were observed when signatures of otoliths from juveniles captured in Thau Lagoon in autumn 2003 were compared with those from autumn 2004, suggesting that these fish had been exposed to globally homogenous conditions during this period in this lagoon (salinity of $36.4 \pm 1.1$ and $35.0 \pm 1.8$, respectively). Moreover, winter 2003-04 was characterized by a 100 -year return flood of the River Rhône, whereas in winter 2002-03 there was no exceptional flood. Otolith signatures from fish born in winter 2003-04 revealed high $\mathrm{Ba} / \mathrm{Ca}$, low $\mathrm{Sr} / \mathrm{Ca}$ and low $\delta^{13} \mathrm{C}$ in relation to the flood. The absence of difference in juvenile signatures suggests that the larval life stage has not interfered with signatures observed for these two years. Our study thus shows that elemental and isotopic otolith compositions can be used as a tracer in adult populations of fish having used this lagoon as a nursery grounds. However, several studies have shown that group-specific variation in elemental composition is more the rule than the exception (Thorrold et al. 1997, Campana et al. 2000). Thus, the homogeneity observed in Thau Lagoon could have varied in other years. Use of this elemental composition as a biological marker was only possible in fish that used Thau Lagoon during the two years studied.

Otolith elemental fingerprints separate juveniles from both lagoons and juveniles from Thau Lagoon and the River Rhône mouth. These differences suggest that the environmental characteristics of each lagoon were sufficient to enable the identification of fish origins during this life stage. As noted above, $\mathrm{Sr} /$ $\mathrm{Ca}$ and $\mathrm{Co} / \mathrm{Ca}$ ratios are higher in marine water than in freshwater (Limburg 1995, Campana 1999, Secor and Rooker 2000, Panfili et al. 2002, Zlokovitz et al. 2003, Zimmerman 2005), whereas $\mathrm{Ba} / \mathrm{Ca}$ and $\mathrm{Mn} / \mathrm{Ca}$ show higher values in freshwater than in marine water (Panfili et al. 2002, Hamer et al. 2006, Bradbury et al. 2008, Tabouret et al. 2010). Higher $\mathrm{Sr} / \mathrm{Ca}, \mathrm{Co} / \mathrm{Ca}$ and $\mathrm{Cu} / \mathrm{Ca}$ ratios were observed in otoliths from juveniles captured in Thau Lagoon than in those captured in Mauguio Lagoon. The differences observed for these ratios may be related to the higher salinity observed in Thau Lagoon ( 32-39) than in Mauguio Lagoon ( 1832, Ifremer 2008). The Thau and Mauguio lagoons 
have different watersheds, which may explain the differences in $\mathrm{Cu} / \mathrm{Ca}$ values. Mauguio is very close to the city of Montpellier (400000 inhabitants including the suburbs: Mouillot et al. 2005) and Thau is surrounded by several small towns with a total of approximately 90000 inhabitants. The area is the home to considerable agricultural activity such as vineyards, which represent $36 \%$ of the watershed (Ifremer 2004). Moreover, tourism activities located around both lagoons explain seasonal swings in population. Through surface runoff, both lagoons accumulate pollution from urban and agricultural activities (such as copper from vineyards).

Although our results were obtained on a small number of individuals, juveniles captured in Thau Lagoon show higher $\mathrm{Ba} / \mathrm{Ca}$ and $\mathrm{Mn} / \mathrm{Ca}$ ratios than those captured at the River Rhône mouth. Otoliths from shallow nurseries show high barium concentrations in various species (Hamer et al. 2006, Leakey et al. 2009, Cuveliers et al. 2010). Ambient barium sources include terrestrial runoff, groundwater, pollution and remobilization from sediments (Hamer et al. 2006). High manganese values in otoliths have been observed for Solea solea in the Wadden Sea (Cuveliers et al. 2010) and are explained by an enrichment of Mn linked to increased microbial activity during summer. This is a robust indication that these two ratios $(\mathrm{Ba} / \mathrm{Ca}$ and $\mathrm{Mn} / \mathrm{Ca})$ may be useful to characterize fish from waters having contrasting seasonal parameters. Juveniles captured at the River Rhône mouth show lower $\mathrm{Cd} / \mathrm{Ca}$ ratio values than those from Thau Lagoon. $\mathrm{Cd}$ and $\mathrm{Mn}$ concentrations are also higher in lagoonal waters than in sea waters, probably because of the enrichment in both dissolved and particulate elements of brackish lagoonal waters (Cuveliers et al. 2010). Cadmium is usually associated with allochthonous inputs, whereas manganese is associated with organic matter inputs (Péna and Picot 1991, Metzger et al. 2007). Thau Lagoon is surrounded by several small towns with a total of approximately 90000 inhabitants. Moreover, the human population increases considerably in summer with tourism activities around both lagoons. The lagoon accumulates pollution from urban and agricultural activities through surface runoff. In addition, chemical elements drain into the lagoon from inflow Rivers. Péna and Picot (1991) showed that Thau sediments were principally composed of silts (45\%), and found cadmium in the vicinity of the major river flowing into the lagoon. Roussiez et al. (2006) showed that metal contamination (cadmium) has accumulated in the silt fraction in the direct vicinity of the River Rhone mouth. Differences in otolith metal concentrations have provided the basis for a tag which can be used to discriminate between coastal and lagoonal marine S. solea. Detritivorous "polychaetes" are abundant in lagoons (Duport et al. 2007), where they make up the main part of the $S$. solea diet (Darnaude et al. 2001). Consequently, these invertebrates have been clearly identified as the major pathway for the transfer of organic matter into those food webs which culminate with the common sole (Darnaude et al. 2004). Recently, Amiard et al. (2007) illustrated the bioaccumulation of cadmium in a "polychaete", Nereis deversicolor, related to increasing concentrations of labile cadmium in sediment. It is thus likely that metal contamination from sediment to $S$. solea could occur through the trophic network, via detritivorous "polychaetes". However, incorporation of cadmium through the dissolved inorganic materials from resuspension events may also be another hypothesis. The differences observed in otoliths seem to be due to the differences between both habitats, but a variation of conditions cannot be excluded between both years.

Although the results were obtained using a small number of individuals, nurseries exhibit differences in isotopic ratios, with an increase in $\delta^{13} \mathrm{C}$ from Mauguio Lagoon to Thau Lagoon, and lower $\delta^{18} \mathrm{O}$ values in otoliths from juveniles captured in Mauguio Lagoon. $\delta^{18} \mathrm{O}$ is negatively correlated with temperature and positively correlated with salinity (Panfili et al. 2002). Differences in $\delta^{18} \mathrm{O}$ observed between nurseries may reflect the differences in site salinity, with lower salinity occurring in Mauguio Lagoon (Ifremer 2008). In otoliths, $\delta^{13} \mathrm{C}$ reflects the metabolism (diet) and DIC signatures (Thorrold et al. 1997, Høie et al. 2004, Solomon et al. 2006). The $\delta^{13} \mathrm{C}$ variation may thus reflect both a change in diet due to the different prey species eaten in each nursery (Rosenberg et al. 2003) and also DIC signatures, which are lower in water influenced by terrestrial inputs (Vizzini et al. 2005) than in marine water (Aucour et al. 2003). Higher values in otoliths from juveniles captured in Thau Lagoon suggest a stronger marine influence on this lagoon than on the two other nurseries. Moreover, $\delta^{13} \mathrm{C}$ variations may reflect differences in the portion of $\delta^{13} \mathrm{C}$ from the diet. Recent studies on common sole muscle tissue have revealed differences in $\delta^{13} \mathrm{C}$ signatures in relation to differences observed in the $\delta^{13} \mathrm{C}$ of the particular organic matter (POM) at the base of the trophic network (Darnaude 2003, 2005, Dierking et al. 2012). These differences may result from the more terrestrial origin of POM in Mauguio Lagoon than at the River Rhône mouth or in Thau Lagoon.

\section{Adult life}

Although our results were obtained using a small number of individuals, the otoliths of adults show differences for isotopic signatures only. Isotopic signatures are linked to water parameters (such as temperature, salinity and DIC, Thorrold et al. 1997, Høie et al. 2004, Solomon et al. 2006). Adults were captured at the same depth in the eastern part of the Gulf of Lions, where temperature and salinity are similar. The differences observed for $\delta^{18} \mathrm{O}$ may result from environments previously inhabited by the fish (larval or juvenile life stages). Otolith $\delta^{13} \mathrm{C}$ was higher in adults captured at Saintes-Maries than in those captured in deep water at the River Rhône mouth. Whereas both sites are located in proximity to the River Rhône mouth, the differences 
observed could suggest that the Saintes-Maries area is less influenced by river inputs than the area located near the River Rhône mouth. This signature could also reflect a difference in the signature of the environment previously inhabited by soles during their larval and/or juvenile phases.

\section{Ontogenetic effect}

Of the 11 elemental ratios, four (Fe/Ca, $\mathrm{Mn} / \mathrm{Ca}, \mathrm{Mg}$ / $\mathrm{Ca}$ and $\mathrm{Co} / \mathrm{Ca}$ ) showed a significant correspondence with fish size. The life cycle of the common sole in the NW Mediterranean Sea is characterized by an ontogenetic shift in habitat. Juveniles inhabit shallow marine waters, whereas adults inhabit deeper marine environments (Salen-Picard et al. 2002). Cobalt is more concentrated in otoliths from marine environments than in those from fish caught in brackish waters, and the opposite is observed for manganese (Panfili et al. 2002). Roussiez et al. (2006) showed an association between this element and the clay fraction in sediments, which increased with depth. This conformity could explain the increase of the $\mathrm{Co} / \mathrm{Ca}$ ratio observed for fish size and the decrease observed for the $\mathrm{Mn} / \mathrm{Ca}$ ratio. Iron and magnesium ratios were seen to decrease with fish size. Relationships between these environmental concentrations and otolith bio-mineralization are not clear (Panfili et al. 2002) and variations may be due to ontogenetic effects. These differences could also reflect a migration of individuals between contrasted habitats during their life.

Moreover, otolith chemical composition enabled discrimination between individuals according to their life cycle stage. The differences observed may be due to the ontogenetic shift in habitat use. As we have shown previously, during each life cycle phase the common sole lives in different habitats, each with specific environmental characteristics. Adults showed high $\mathrm{Co} /$ $\mathrm{Ca}$ ratios associated with the clay sediments present in deep water near the River Rhône mouth. In general, juveniles were a separate group, showing $\mathrm{Sr} / \mathrm{Ca}$ and $\mathrm{Cu} / \mathrm{Ca}$ ratios in relation to salinity and allochthonous inputs from the watersheds. The larval stage was associated with higher $\mathrm{Mg} / \mathrm{Ca}$ values. All these differences seem to suggest that otolith elemental composition of the common sole is more strongly influenced by modifications of environmental characteristics during their life cycle than by ontogeny.

Although preliminary, our results show a differentiation of each life stage by otolith elemental composition, probably related to differences in environmental conditions between sites or years. Moreover, they suggest that the SB-ICPMS of whole otoliths is inappropriate for life-history studies. Indeed, the elemental composition acquired during one life stage is masked by those acquired during the next stages of life. These results, obtained on limited sample numbers, must be confirmed by other analyses involving greater numbers of individuals. However, the differences observed in various environments for the same stage suggest that otolith microchemistry could provide information on fish migration, if better-adapted techniques such as LA-ICPMS were used.

\section{ACKNOWLEDGEMENTS}

This study represents a portion of the first author's $\mathrm{PhD}$ thesis and is financed by the Conseil Régional Provence Alpes-Côtes d'Azur, the Fondation Total and the Agence de l'Eau Rhône Méditerranée-Corse, and is a part of the ANR program "LAGUNEX". Dominique Blamart thanks CEA for analytical support. We thank Mrs Rachel Mackie, as a native English speaker, for proof-reading the manuscript, and the anonymous reviewers for their useful comments. We thank Mrs Carmen Palacios for the translation of the Spanish abstract.

\section{REFERENCES}

Amiard J-C., Geffard A., Amiard-Triquet C., Crouzet C. 2007. Relationship between the lability of sediment-bound metals $(\mathrm{Cd}$, $\mathrm{Cu}, \mathrm{Zn}$ ) and their bioaccumulation in benthic invertebrates. Estuar. Coast. Shelf Sci. 72: 511-521.

Aucour A-M., Sheppard S.M.F., Savoye R. 2003. $\delta^{13} \mathrm{C}$ of fluvial mollusk shells (Rhône River): A proxy for dissolved inorganic carbon? Limnol. Oceanogr. 48: 2186-2193.

Blamart D., Escoubeyrou K., Juillet-Leclerc A., Ouahdi R., Lecomte-Finiger R. 2002. Composition isotopique $\delta^{18} \mathrm{O}-\delta^{13} \mathrm{C}$ des otolithes des populations de poissons récifaux de Taiaro (Tuamotu, Polynésie française): implications isotopiques et biologiques. C. R. Biol. 325: 99-106.

Bradbury I.R., Campana S.E., Bentzen P. 2008. Otolith elemental composition and adult tagging reveal spawning site fidelity and estuarine dependency in rainbow smelt. Mar. Ecol. Prog. Ser. 368: $255-268$

Campana S.E. 1999. Chemistry and composition of fish otoliths: pathways, mechanisms and applications. Mar. Ecol. Prog. Ser. 188: 263-297.

Campana S.E., Casselman J.L. 1993. Stock discrimination using otolith shape analysis. Can. J. Fish. Aquat. Sci. 50: 1062-1083.

Campana S.E., Chouinard G.A., Hanson J.M., Fréchet A. 1999. Mixing and migration of overwintering Atlantic cod (Gadus morhua) stocks near the mouth of the Gulf of St. Lawrence. Can. J. Fish. Aquat. Sci. 56: 1873-1881.

Campana S.E., Chouinard G.A., Hanson J.M., Fréchet A., Brattey J. 2000. Otolith elemental fingerprints as biological tracers of fish stocks. Fish. Res. 46: 343-357.

Campana S.E., Gagné J.A., McLaren J. 1995. Element fingerprinting of fish otoliths using ID-ICPMS. Mar. Ecol. Prog. Ser. 122: $115-120$.

Campana S.E., Neilson J.D. 1985. Microstructure of fish otoliths. Can. J. Fish. Aquat. Sci. 42: 1014-1031

Campillo A. 1992. Les pêcheries françaises de Méditerranée: synthèse des connaissances. IFREMER, RIDRV-92/019- RH, Sète, France, 206 pp.

Campillo A., Aldebert Y., Bigot J.L., Liorzou B. 1989. Donnée de distribution des principales espèces commerciales du Golfe du Lion. Rapports internes de la direction des ressources vivantes de l'IFREMER, DRV-89.041RH/, Sète, France, 175 pp.

Coplen T.B., Kendall C., Hopple J. 1993. Comparison of stable isotope reference samples. Nature 302: 236-238.

Cuveliers E.L., Geffen A.J., Guelinckx J., Raeymaekers J.A.M., Skadal J., Volckaert F.A.M., Maes G.E. 2010. Microchemical variation in juvenile Solea solea otoliths as a powerful tool for studying connectivity in the North Sea. Mar. Ecol. Prog. Ser. 401: 211-220.

Darnaude A. 2003. Apports fluviaux en zone côtière et réseaux trophiques marins benthiques: transfert de matière organique particulaire terrigène jusqu'aux poissons plats au large du Rhône. Thèse de Doctorat, spécialité Biosciences de 
l'Environnement, Chimie et Santé, Université de la Méditerranée, Marseille, France, 373 pp.

Darnaude A.M. 2005. Fish ecology and terrestrial carbon use in coastal areas: implications for marine fish production. J. Anim. Ecol. 74: 864-876.

Darnaude A.M., Harmelin-Vivien M.L., Salen-Picard C. 2001. Food partitioning among flatfish (Pisces: Pleuronectiforms) juveniles in a Mediterranean coastal shallow sandy area. J. Mar. Biol. Assoc. U.K. 81: 119-127.

Darnaude A.M., Salen-Picard C., Polunin N.V.C., Harmelin-Vivien M.L. 2004. Trophodynamic linkage between river runoff and coastal fishery yield elucidated by stable isotope data in the Gulf of Lions (NW Mediterranean). Oecologia 138: 325-332.

Demaneche S., Merrien C., Berthou P., Lespagnol P. 2009. Rapport R3, Méditerranée continentale, échantillonnage des marées au débarquement. Méthode d'élévation et évaluation des captures et de l'effort de pêche des flottilles de la façade Méditerranée continentale sur la période 2007-2008. Ifremer, France, 217 pp.

Dierking J., Morat F., Letourneur Y., Harmelin-Vivien M. 2012. Fingerprints of lagoonal life: Migration of the marine flatfish Solea solea assessed by stable isotopes and otolith microchemistry. Estuar. Coast. Shelf Sci. 104-105: 23-32.

Duport E., Gilbert F., Poggiale J.C., Dedieu K., Rabouille C., Stora G. 2007. Benthic macrofauna and sediment reworking quantification in contrasted environments in the Thau Lagoon. Estuar. Coast. Shelf Sci. 72: 522-533.

Farrell J., Campana S.E. 1996. Regulation of calcium and strontium deposition on the Otoliths of Juvenile Tilapia, Oreochromis niloticus. Comp. Biochem. Physiol. 115A: 103-109.

Fowler A.J., Campana S.E., Jones C.M., Thorrold S.R. 1995 Experimental assessment of the effect of temperature and salinity on elemental composition of otoliths using solution-based ICPMS. Can. J. Fish. Aquat. Sci. 52: 1421-1430.

Friendland K.D., Reddin D.G. 1994. Use of otolith morphology in stock discrimination of Atlantic salmon (Salmo salar). Can. J. Fish. Aquat. Sci. 51: 91-98

Gaertner J.C., Chessel D., Bertrand J. 1998. Stability of spatial structures of demersal assemblages: a multiple approach. Aquat. Living Resour. 11: 75-85.

Gallahar N.K., Kingsford M.J. 1996. Factors influencing Sr/Ca ratios in otoliths of Girella elevatar: an experimental investigation. J. Fish Biol. 48: 161-131.

Garcia S.M., Cochrane K., Van Santen G., Christy F. 1999. Towards sustainable fisheries: a strategy for FAO and the World Bank. Ocean Coast. Manage. 42: 369-398.

Gillanders B.M. 2002. Connectivity between juvenile and adult fish populations: do adults remain near their recruitment estuaries? Mar. Ecol. Prog. Ser. 240: 215-223.

Gillanders B.M., Kingsford M.J. 1996. Elements in otoliths may elucidate the contribution of estuarine recruitment to sustaining coastal reef populations of a temperate reef fish. Mar. Ecol. Prog. Ser. 141: 13-20.

Gillanders B.M., Kingsford M.J. 2000. Elemental fingerprints of otoliths of fish may distinguish estuarine 'nursery' habitats. Mar. Ecol. Prog. Ser. 201: 276-286.

Hamer P.A., Jenkins G.P., Coutin P. 2006. Barium variation in $\mathrm{Pa}-$ grus auratus (Sparidae) otoliths: A potential indicator of migration between an embayment and ocean waters in south-eastern Australia. Estuar. Coast. Shelf Sci. 68: 686-702.

Høie H., Andersson C., Folkvord A., Karlsen Ø. 2004. Precision and accuracy of stable isotope signals in otoliths of pen-reared cod (Gadus morhua) when sampled with a high-resolution micromill. Mar. Biol. 144: 1039-1049.

Ifremer. 2004. Réseau de suivi lagunaire du Languedoc-Roussillon: Bilan des résultats 2003. Rapport RSL 04-2004. 226 pp.

Ifremer. 2008. Réseau de suivi lagunaire du Languedoc-Roussillon: Bilan des résultats 2007. Rapport RSL 08-2008. 363 pp.

Kalish J.M. 1989. Otolith microchemistry: validation of the effects of physiology, age and environment on otolith composition. $J$. Exp. Mar. Biol. Ecol. 132: 151-178.

Kalish J.M. 1991. Oxygen and carbon stable isotopes in the otoliths of wild and laboratory-reared Australian salmon (Arripis trutta). Mar. Biol. 110: 37-47.

Kemp W.M., Boynton W.R., Adolf J.E., Boesch D.F., Boicourt W.C., Brush G., Cornwell J.C., Fisher T.R., Glibert P.M., Hagy J.D., Harding L.W., Houde E.D., Kimmel D.G., Miller W.D., Newell R.I.E., Roman M.R., Smith E.M., Stevenson J.C. 2005.
Eutrophication of Chesapeake Bay: historical trends and ecological interactions. Mar. Ecol. Prog. Ser. 303: 1-29.

Kerr L.A, Secor D., Kraus R.T. 2007. Stable isotope $\left(\delta^{13} \mathrm{C}\right.$ and $\left.\delta^{18} \mathrm{O}\right)$ and $\mathrm{Sr} / \mathrm{Ca}$ composition of otoliths as proxies for environmental salinity experienced by an estuarine fish. Mar. Ecol. Prog. Ser. 348: 245-253.

Leakey C.D.B., Attrill M.J., Fitzsimons M.F. 2009. Multi-element otolith chemistry of juvenile sole (Solea solea), whiting (Merlangius merlangus) and European seabass (Dicentrarchus labrax) in the Thames Estuary and adjacent coastal regions. J. Sea Res. 61: 268-274.

Lecomte-Finiger R. 1999. L'otolithe : la "boîte noire" des Téléostéens. Ann. Biol. 38: 107-122.

Limburg K.E. 1995. Otolith strontium traces environmental history of subyearling American shad Alosa sapidissima. Mar. Ecol. Prog. Ser. 119: 25-35.

Mercier L., Mouillot D., Bruguier O., Vigliola L., Darnaude A. 2012. Multi-element otolith fingerprints unravel sea-lagoon lifetime migrations of gilthead sea bream Sparus aurata. Mar. Ecol. Prog. Ser. 444: 175-194.

Mérigot B., Letourneur Y., Lecomte-Finiger R. 2007. Characterization of local populations of the common sole Solea solea (Pisces, Soleidae) in the NW Mediterranean through otolith morphometrics shape analysis. Mar. Biol. 151: 997-1008.

Metzger E., Simonucci C., Viollier E., Sarazin G., Prévot F., Jézéquel D. 2007. Benthic response to shellfish farming in Thau lagoon: Pore water signature. Estuar. Coast. Shelf Sci. 72: 406-419.

Miralles J., Arnaud M., Radakovitch O., Marion C., Cagnat X. 2006. Radionuclide deposition in the Rhône River Prodelta (NW Mediterranean Sea) in response to the December 2003 extreme flood. Mar. Geol. 234: 179-189.

Morat F., Letourneur Y., Nérini D., Banaru D., Batjakas I.E. 2012. Discrimination of red mullet populations (Teleostean, Mullidae) along multi-spatial and ontogenetic scales within the Mediterranean basin on the basis of otolith shape analysis. Aquat. Living Resour. 25: 27-39.

Mouillot D., Gaillard S., Aliaume C., Verlaque M., Belsher T., Troussellier M., Do Chi T. 2005. Ability of taxonomic diversity indices to discriminate coastal lagoon environments based on macrophyte communities. Ecol. Indic. 5: 1-17.

Myers R.A., Worm B. 2003. Rapid worldwide depletion of predatory fish communities. Nature 423: 280-283.

Nixon S. 1995. Coastal marine eutrophication: a definition, social causes, and future concerns. Ophelia 41: 199-219.

Panfili J., de Pontual H., Troadec H., Wright P.J. (eds). 2002. Manuel de sclérochronologie des poissons. Coédition IfremerIRD, France, $464 \mathrm{pp}$.

Péna G., Picot B. 1991. Métaux traces dans les sédiments d'une lagune méditerranéenne: l'étang de Thau. Oceanol. Acta 14: $459-471$.

Pothin K., Gonzalez-Salas C., Chabanet P., Lecomte-Finiger R. 2006. Distinction between Mulloidichthys flavoneatus juvenile from Reunion Island and Mauritius Island (South-West Indian Ocean) based on otolith morphometrics. J. Fish Biol. 68: 1-16.

Quéro J.C., Vayne J.J. 1997. Les poissons de mer des pêches françaises, identification, inventaire et répartition de 209 espèces. Delachaux et Niestlé (eds), Paris, France, 304 pp.

Ramsay J.O., Silveman B.W. 2005. Functional data analysis. Springer, New-York, USA, 2nd edition, $310 \mathrm{pp}$.

Reddin D.G., Stansbury D.E., Short P.B. 1988. Contigent of origin of Atlantic salmon (Salmo salar L.) at West Greenland. J. Cons. Int. Explor. Mer 44: 180-188.

Rooker J.R., Secor D., Zdanowicz V.S., DeMetrio G., Orsi Relini L. 2003. Identification of Atlantic bluefin tuna (Thunnus thynnus) stocks from putative nurseries using otolith chemistry. Fish. Oceanogr. 12: 75-84.

Rooker J.R., Secor D.H., DeMetrio G., Kaufman A.J., Belmonte R.A., Vjekoslav T. 2008a. Evidence of trans-Atlantic movement and natal homing of bluefin tuna from stable isotopes in otoliths. Mar. Ecol. Prog. Ser. 368: 231-239.

Rooker J.R., Secor D.H., DeMetrio G., Schloesser R., Block B.A., Neilson J.D. 2008b. Natal Homing and Connectivity in Atlantic Bluefin Tuna Populations. Science 322: 742-744.

Rosenberg R., Grémare A., Amouroux J.M., Nilsson H.C. 2003. Benthic habitats in the northwest Mediterranean characterised by sedimentary organics, benthic macrofauna and sediment 
profile images. Estuar. Coast. Shelf Sci. 57: 297-311.

Roussiez V., Ludwig W., Monaco A., Probst J.L., Bouloubassi I., Buscail R., Saragoni G. 2006. Sources and sinks of sedimentbound contaminants in the Gulf of Lions (NW Mediterranean Sea): A multi-tracer approach. Contin. Shelf Res. 26: 1843-1857.

Salen-Picard C., Darnaude A., Arlhac D., Harmelin-Vivien M.L. 2002. Fluctuations of macrobenthic populations: a link between climate-driven river run-off and sole fishery yields in the Gulf of Lions. Oecologia. 133: 380-388.

Schwarcz H.P., Gao Y., Campana S.E., Browne D., Knyf M., Brand U. 1998. Stable carbon isotope variations in otoliths of Atlantic cod (Gadus morhua). Can. J. Fish. Aquat. Sci. 55: 1798-1806.

Secor D.H., Rooker J.R. 2000. Is otolith strontium a useful scalar of life cycles in estuarine fishes? Fish. Res. 46: 359-371.

Solomon C.T., Weber P.K., Cech Jr. J.J., Ingram B.L., Conrad M.E., Machavaram M.V., Pogodina A.R., Franklin R.L. 2006. Experimental determination of the sources of otolith carbon and associated isotopic fractionation. Can. J. Fish. Aquat. Sci. 63: 79-89.

Tabouret H., Bareille G., Claverie F., Pécheyran C., Donard O.F.X. 2010. Simultaneous use of strontium: calcium and barium: calcium ratios in otoliths as markers of habitat: Application to the European eel (Anguilla anguilla) in the Adour basin, South West France. Mar. Environ. Res. 70: 35-45.

Tanner S.E., Vasconcelos R.P., Reis-Santos P., Cabral H.N., Thorrold S.R. 2011. Spatial and ontogenetic variability in the chemical composition of juvenile common sole (Solea solea) otoliths. Estuar. Coast. Shelf Sci. 91: 150-157.
Thorrold S.R., Campana S.E., Jones C.M., Swart P.K. 1997. Factors determining $\delta^{13} \mathrm{C}$ and $\delta^{18} \mathrm{O}$ fractionation in aragonitic otoliths of marine fish. Geochim. Cosmochim. Acta 61: 2909-2919.

Titus K., Mosher J.A., Williams B.K. 1984. Chance-corrected classification for use in discriminant analysis: ecological applications. Am. Midl. Nat. 111: 1-7.

Tracey S.R., Lyle J.M., Duhamel G. 2006. Application of elliptical Fourier analysis of otolith form as a tool for stock identification. Fish. Res. 77: 138-147.

Vasconcelos R.P., Reis-Santos P., Tanner S., Maia A., Latkoczy C., Günther D., Costa M.J., Cabral H. 2008. Evidence of estuarine nursery origin of five coastal fish species along the Portuguese coast through otolith elemental fingerprints. Estuar. Coast. Shelf Sci. 79: 317-327.

Vizzini S., Savona B., Chi T., Mazzola A. 2005. Spatial variability of stable carbon and nitrogen isotope ratios in a Mediterranean coastal lagoon. Hydrobiologia 550: 73-82.

Zimmerman C.E. 2005. Relationship of otolith strontium-to-calcium ratios and salinity: experimental validation for juvenile salmonids. Can. J. Fish. Aquat. Sci. 62: 88-97.

Zlokovitz E.R., Secor D.H., Piccoli P.M. 2003. Patterns of migration in Hudson River striped bass as determined by otolith microchemistry. Fish. Res. 63: 245-259.

Scient ed.: I. Palomera.

Received May 2, 2012. Accepted September 6, 2012

Published online November 9, 2012. 